\title{
Polysemy in Linguistic Terminological Systems Based on the Analysis of French Linguistic Terms
}

\author{
Denis Zolotukhin \\ Moscow Pedagogical State University
}

\begin{abstract}
Correspondence concerning this article should be addressed to Denis Zolotukhin, Romance Languages Department, Moscow State Pedagogical University, Russia, 88 prospekt Vernadskogo, Moscow, Russia, 119571.E-mail: denzolotukhin@gmail.com
\end{abstract}

\begin{abstract}
The article reports on the features of polysemy in French terminological systems of linguistics at inter-system and intra-system levels. The existing studies concerning terminological semantics allow pointing out two aspects of the term structure: a semantic structure representing a complex of meanings, and a structure of the terminological meaning representing a complex of semes. The first aspect supposes the analysis of terminological polysemy regarded as a negative characteristic of terms. According to the second aspect some particularities of denotative and significative levels and their correlation to scientific concepts can be analyzed. In the given study the component analysis of the definitions of French terms - such as 'sémantème', 'mot' and 'signe' - reveals different types of polysemy and terminological variation. The analysis of semantic structures of these terms shows that terminological deviations are caused by objective differences at significative and denotative levels of the meaning as well as by the subjective use of occasional contexts of terms in linguistic research. The suggested results allow constructing a new classification of meaning relations of linguistic terms. Each type of relations is correlated to different elements of the term structure. The hierarchy of these elements is embodied into an abstract model that can be applied for the analysis of any term of the modern linguistic terminology.
\end{abstract}

Keywords: terminology, polysemy, concept, meaning, variation, seme

A terminological system is usually described as a part of a general linguistic system. However, the notion of a part can be correlated to a term itself being a set of system elements. The elements included in the structure of the term are, at the same time, elements of a larger system, called a 'terminological' system. Kharitonova indicates the unity of an integer and its parts having common properties (Kharitonova, 2004, p. 40). If terms are considered as specific lexical units, among linguistic approaches to the study of terms the method of component analysis allowing the semantic study of terminological system elements is of great importance. The component analysis is characterized as a method that involves consideration of the semantic structure of terms dismembering it into components - semes. A seme can be defined as the smallest unit of the terminological content. Each seme is connected to other semes forming a hierarchy in the meaning structure 'imitating' the structure of scientific concepts. If the definition is considered as the expansion of the terminological meaning, the method of component analysis of definitions of the term can be applied in the given research.

The polysemy of linguistic terms, being characterized as an undesirable feature of an ideal terminological system, is a common phenomenon that, according to Bursina (2014), is due to the transition of words to the category of terms, as well as the transition of elements from one terminological system to another (p. 66). The so-called intercategorical polysemy is introduced by Leitchik as a common feature of terminological systems. For Leitchik the inter-categorical polysemy can be also characterized as a semantic homonymy (Leitchik, 2012, p. 109). Sometimes one of the homonymous lexical units is replaced and the semantic homonymy is eliminated, for example in Classification (object) Classifying (process). Nevertheless, it is clear that the phenomenon of polysemy as well as the phenomenon of semantic homonymy are characteristic for any terminology.

The main reason for the linguistic polysemy of a 
term should be explained by one of the characteristics of its meanings: a strong interaction between denotative and significative components forming, in its entirety, a significo-denotative component that relates to the area of scientific concepts in a term structure. Kosova (2003) notes that meanings of one word can refer to the same object but to different concept areas: they have a common linguistic reality, but suggest its different conceptual features (p. 66). Terminological meanings may also have unequal objective and conceptual correlations. Khodakova (2010) states that terminological polysemy may be due to two reasons: the correlation of one term with different denotative components or different significative components ( $p$. 179). This paper aims to analyze polysemy features of French linguistic terms caused by the differences at denotative and significative levels.

\section{Materials and Methods}

\section{Denotative and Significative Correlations}

It is necessary to take into account a fundamental distinction between the semantic structure and the structure of a lexical meaning. Sternin (1979) considers the semantic structure as all lexical-semantic variants of a word, while the structure of a lexical meaning being a set of semantic features (semes) defined in one lexical meaning (p. 23). In Shurigin's (2005) terminological studies the semantic structure of a linguistic term is also defined as a system of lexical-semantic variants of a multiple-meaning word or as a system of meaning components of a one-meaning word - a set of semes (the smallest components of a lexical meaning) (p. 88). All semes in one terminological meaning can be divided into, at least, two groups: denotative and significative. Thus, the semantic structure and the structure of a terminological meaning represent two aspects of the term (see Figure 1).

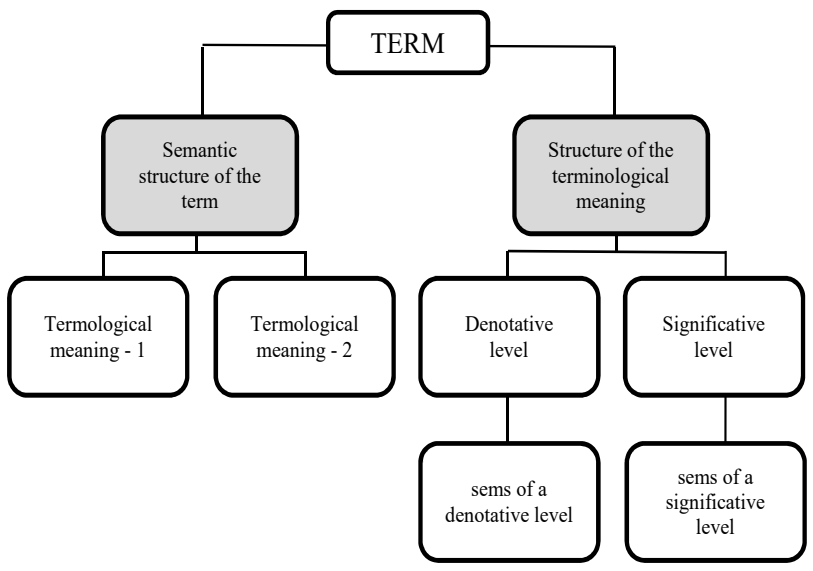

Figure 1. Aspects of the term structure.
Some lexical units also include a connotative level in their meaning structures. As for terms, they are usually deprived of connotative components. However, it should be noted that the lack of connotation is rather an optional feature for the terminological vocabulary. This fact can be particularly applied to the terms of human sciences where the understanding of one concept inevitably involves the appearance of connotative shades. Any operation on scientific concepts always includes connotative representations of the scientist - his personal attitude. It should also be mentioned that the terms are actualized in scientific texts often carrying connotative elements, as indicated by Kosova (2003, p. 74). These elements are constantly integrating in terminological meanings being fixed in some terminologies. Thus, in this study, it is advisable to speak rather about the weak role of connotative components in linguistic terms and not about their complete absence.

Components of both significative and denotative levels can be described, as it was mentioned above, by a single term - significo-denotative component as an equivalent in semantics for a scientific concept in logics. The volume of a scientific concept is presented at the denotative level of the terminological meaning and the significative level is the content of this scientific concept. The signification of the object implies an access to its conceptual characteristics that correspond to the positions from which the object is considered in one particular research area. The logic of scientific research leads to the generalization of the object being studied; the appearance of its conceptual characteristics forms a substantial part of the concept. The scientific concept gets expressed in the language with the help of the terminological meaning. The simultaneous expression of a class of objects (denotative components) and their interpretation (significative components) takes place. The observed interaction of these two levels allows correlating the scientific concept with significodenotative components of the terminological meaning.

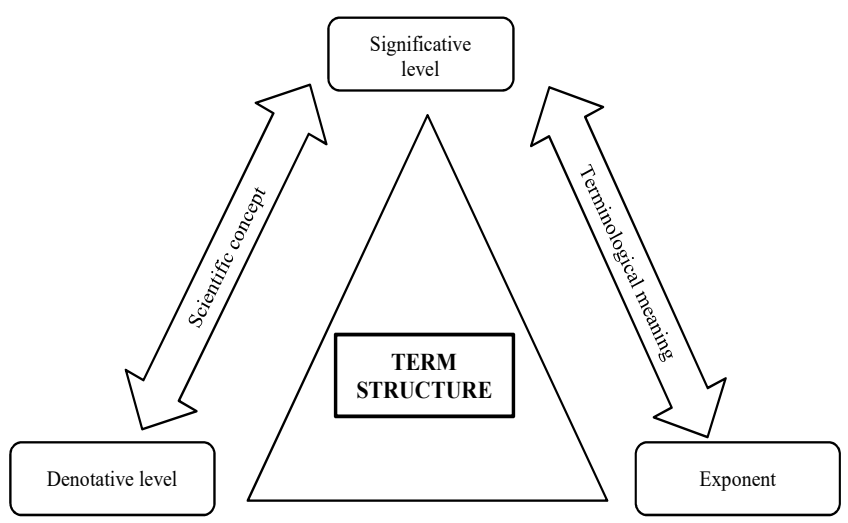

Figure 2. Correlation between the scientific concept and the terminological meaning. 
The latter corresponds to a certain exponent (a form, a signifier) in the formal side of the language. This confirmation can be displayed in the following figure (see Figure 2) showing a modified version of a wellknown semantic triangle reflecting general features of the term structure.

This scheme shows that the terminological meanings express scientific concepts. However, one can hardly agree with Bursina describing the term as a 'mirror' of a scientific concept through its terminological meaning (2014, p. 30). Given the nature of scientific concepts described in linguistics, Shurigin seems to be right stating that the concept and the meaning do not have the same value because the main characteristics of the concept are expressed in denotative components of the meanings while its significative components include the interpretation of this concept. It appears that some subjective factor of the process of signification does not allow deducing the entire content of the scientific concept to one terminological meaning. Khodakova also notes that the terminological meaning consists of semes representing 'certain cognitive features forming the content of the concept' (2010, p. 156).

Thus, a set of terminological meanings represents the semantic structure of a multiple-meaning (polysemantic) term. The particularities of the semantic structure of a term are caused by the specific features of its separate meaning structures at significative and denotative levels.

A. Correlation of one term with different denotative components (DC): each DC has its own meaning. Given the nature of a DC in a linguistic term, it is necessary to clarify this point by comparing, for example, meanings of a 'sémantème' described by different French linguists. Greimas (1980) defines the term 'sémantème' (semanteme) as 'investissement sémantique d'un morphème ou d'un énoncé' (semantic investment of a morpheme or a statement) (p. 325). Greimas uses this term in order to refer to the semantic core, combined with contextual semes (meaning variations). For B. Poitiers a 'sémantème' denotes a separate group of semes: 'l'ensemble de sèmes spécifiques de l'unité considérée' (a set of specific semes of a considered unit) (cited in Tsybova, 2002, p. 27). In Ch. Bally's theory a 'sémantème' is a term denoting not a content or a part of a unit's content, but a holistic sign expressing a purely lexical meaning (Bally, 1932, p. 64). Therefore, in the presented linguistic theories the term 'sémantème' is correlated with different DCs:

1) a set of semes;

2) a set of specific semes;

3) a sign having lexical meaning.

At the same time, between the meanings (1) and (2) a stable relationship can be observed - synecdoche based on the respect of 'part-whole' (see Figure 3): a DC (an object) and a part of this DC (Kobozeva, 2009, p. 170). The meaning (3) is also associated with the meanings (1) and (2) since it expresses a whole (sign) to a part (a sign's content). These meanings were formed by metonymy that Kosova describes as the cause of terminological polysemy associated with the adjacency of scientific concepts (Kosova, 2009, p. 70). It should be noted that Gadaborsheva (2008) also considers a metaphor as the cause of terminological polysemy ( $p$. 53).

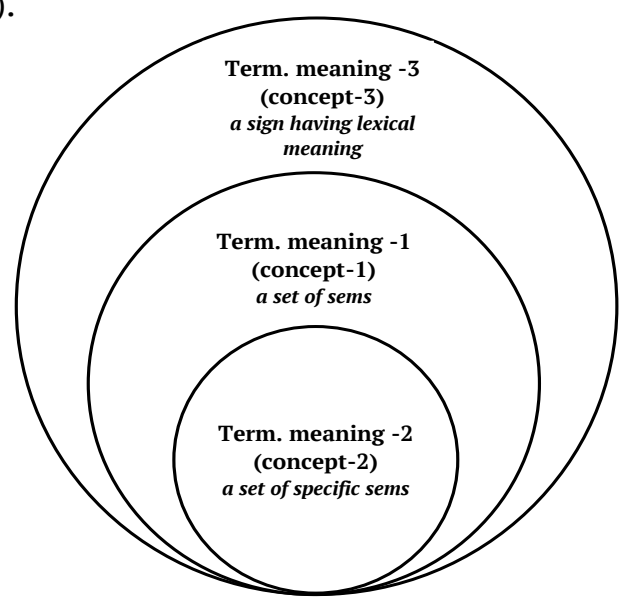

Figure 3. Correlation between three terminological meanings based on synecdoche of the term 'sémantème' (semanteme).

The presence of these links in the semantic structure of three units under consideration allows attributing three meanings to one term - 'sémantème', which is accordingly a multiple-meaning linguistic term denoting three related scientific concepts.

Despite different definitions of these terms their component analysis establishes the absence of $a$ homonymy which can be found only in a complete breakdown in relationship between meanings. Consequently, the establishment of a distinction between terminological polysemy and homonymy requires a consideration of specific features of the relations between terminological meanings expressing a certain denotative component. It can be assumed that homonymy may concern peculiar terms denoting concepts of different scientific fields (compare the meanings of 'langue' (language) in linguistics and 'langue' (tongue) in physiology). As for the homonymy within the frameworks of linguistics, an apt example can be found in the definitions of a 'langue' in semantics (a system of signs) and phonetics (a tongue).

B. Correlation of one term with different significative components (SC): the existence of two or more variants of understanding of the same denotative component, each variant has a different meaning (Khodakova, 2010, p. 179). The polysemy 
of linguistic terms is most often explained by this phenomenon - one term can have several meanings in linguistics, it varies depending on the views of representatives of some linguistic areas. Shurigin (2005) notes that the polysemy of a linguistic term emphasizes its dependence on a particular context; it is a consequence of different points of view on one denotative component - the object of investigation (p. 133). Grinev-Grinevich (2009) also refers to this phenomenon and uses the term euresemy (rus. evrisemia) to indicate a terminological polysemy as a result of its different interpretations (p. 129). This point allows introducing the term of conceptual polysemy to describe a terminological polysemy associated with a significative layer of a meaning. The term of conceptual polysemy can be applied to the co-existence of different meanings of a term ' $m o t$ ' (word) in French linguistics which can be defined from different points of view (phonological, grammatical, lexicological etc.), but each meaning will refer to the same denotative component - 'unité de la langue' (language unit) (see Figure 4).

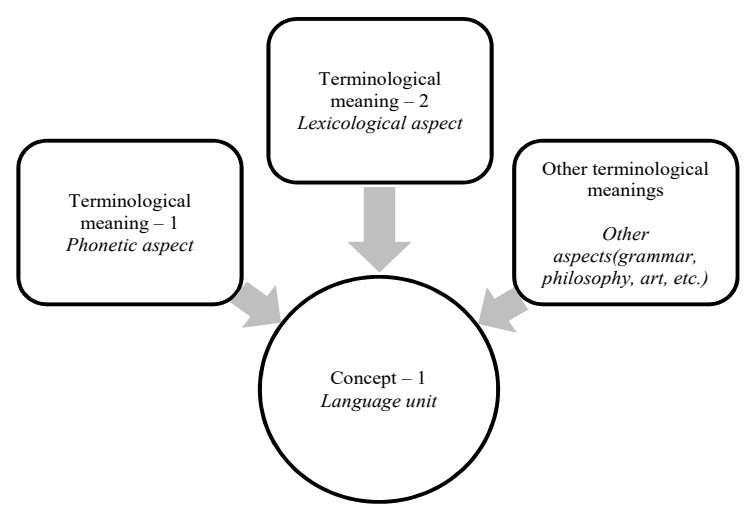

Figure 4. Conceptual polysemy of the term 'mot' (word).

Factors causing terminological polysemy also include an appeal to occasional research contexts in which terms are not always well defined (GrinevGrinevitch, 2009, p. 134). This phenomenon is of a particular importance for the analysis of evolution of linguistic terms: various scholars based on some of their predecessors' works can modify terminological meanings. Such works do not always include contextual definitions carrying out a necessary number of conceptual indicators (meaning components) which are very important for the interpretation of a term.

One can easily see the difference between an occasional context of the term 'signe' (sign):

'Les deux éléments de l'air sont dans l'ordre matériel, et les deux éléments du mot sont réciproquement dans l'ordre spirituel; notre point de vue constant sera de dire que non seulement la signification mais aussi le signe est un fait de conscience pur.' (Saussure, 2002, p. 19)

'The two elements of air belong to the material order, just as the two elements of the word belong to the spiritual order; we shall be consistent in our view that not only the meaning but also the sign is a fact of pure consciousness.' (Saussure, 2006, p. 4)

and a contextual definition of the same term: 'Il y a un premier domaine, intérieur, psychique, où existe le signe autant que la signification, l'un indissolublement lié à l'autre; il y en a un second, extérieur, où n'existe plus que le "signe ", mais à cet instant le signe réduit à une succession d'ondes sonores ne mérite pour nous que le nom de figure vocale.' (Saussure, 2002, p. 21)

'There is one domain, interior, psychic, where both sing and meaning are to be found; and there is another - exterior - domain, where only a «signe » is to be found, but in this case the sign reduced to a series of sound waves deserves in our view only the designation of vocal figure.' (Saussure, 2006, p. 6)

It should be also taken into account that a researcher analyses a formed terminological meaning (or being formed) with particular macro and micro components. They develop and supplement them with a new set of semes pointing to this or that conceptual indicator depending on their own scientific point of view. According to Bursina (2014), a researcher always tries to relate an objective content to its subjective vision necessary for clarifying the boundaries of a scientific concept designated by a term (p. 66).

\section{Results and Discussion}

\section{Terminological Meaning and Its Variants}

It should be noted that Kulikova and Salmina (2002) distinguish the notion of polysemy as a linguistic phenomenon and a conceptual heterogeneity of a terminological meaning as a result of different interpretations of the same denotative component ( $p$. 31). Therefore, sometimes a researcher deals not with a new meaning, but its modification or formation of different variants of the same terminological meaning. This phenomenon is first of all observed in co-existence of different definitions describing the same meaning. A similar opinion is shared by Bugorskaya (2009) stating that the existence of multiple-meaning terms is quite possible, but the ambiguity in the interpretation of the same term by representatives of various scientific disciplines can be considered as a variation of one 
terminological meaning (pp. 211-258).

Slozhenikina (2010) defines a semantic variation of a term as a set of components in a meaning structure that does not match in different interpretations of this meaning, or as a text and lexicographical reflection of the dynamic aspects of change of a term's semantics within the same scientific concept (p. 168). It does not influence paradigmatic and systemic relations of a term. In this study a terminological meaning variation is considered as the ability of a terminological meaning to modify a set of semes in its structure (restriction or expansion) without changing the essence of the meaning and its conceptual reference. $A$ variant of a terminological meaning is then a quotient that is actualized either in a certain context describing a theory or at a certain stage of development of scientific knowledge. Therefore, an invariant of a terminological meaning represents a constant set of significant components. The variation characterizes a term in both synchrony (coexistence of different variants) and diachrony (evolution of a terminological system). For example, Saussure's 'signe' (sign) is known to have a great number of definitions:

association arbitraire d'un signifiant et d'un signifié à l'intérieur d'un système = sème (arbitrary combination of a signifier and a signified within a system $=$ seme); combinaison de deux choses (combination of two things);

être double constitué par une suite de syllabes dans la mesure où on y attache une signification déterminée (double being constituted by a sequence of syllables since a determined meaning is attached); combinaison $d u$ concept avec image acoustique $=$ association [d'un] signifiant [et d'un] signifié [figure] (combination of a concept with an acoustic image = association [of a] signifier [and a] signified [figure]);

entité psychique à deux faces (two-sided psychic entity) (Saussure, 1997, p. 45), etc.

Based on the analysis of 12 different interpretations of the term of signe in Saussure's manuscripts one can say that all these definitions are variants of the same invariant: entité d'un signifié et d'un significant (entity of a signified and a signifier).

The comprehensive review of the semantic structure of the term, as well as the structure of its meanings allow building a content model of one abstract lexical unit including a few terminological meanings that relate to the field of linguistic research. This model reflects all levels of the hierarchical organization of term components. Figure 5 shows the structure of this lexical unit consisting of the following elements:
Table 1

Variation of the terminological meaning of a 'signe' (sign)

\begin{tabular}{|c|c|}
\hline $\begin{array}{l}\text { Terminological } \\
\text { meaning (invariant) }\end{array}$ & $\begin{array}{l}\text { Examples of variants of the } \\
\text { terminological meaning }\end{array}$ \\
\hline \multirow{6}{*}{$\begin{array}{l}\text { entité d'un signifié et } \\
\text { d'un signifiant } \\
\text { (entity of a signified } \\
\text { and a signifier) }\end{array}$} & $\begin{array}{l}\text { association arbitraire d'un signifiant et } \\
\text { d'un signifié (arbitrary combination of a } \\
\text { signifier and a signified within a system } \\
\text { = seme) }\end{array}$ \\
\hline & $\begin{array}{l}\text { combinaison de deux choses } \\
\text { (combination of two things) }\end{array}$ \\
\hline & $\begin{array}{l}\text { être double constitué par une suite de } \\
\text { syllabes (double being constituted by a } \\
\text { sequence of syllables) }\end{array}$ \\
\hline & $\begin{array}{l}\text { combinaison du concept avec image } \\
\text { acoustique (combination of a concept } \\
\text { with an acoustic image) }\end{array}$ \\
\hline & $\begin{array}{l}\text { association [d'un] signifiant [et d'un] } \\
\text { signifié [figure] (association [of a] } \\
\text { signifier [and a] signified [figure]) }\end{array}$ \\
\hline & $\begin{array}{l}\text { entité psychique à deux faces (two-sided } \\
\text { psychic entity) }\end{array}$ \\
\hline
\end{tabular}

- Two commonly used meaning (in general vocabulary) (1 and 2) corresponding to the formal part of the concept (the ordinary concept);

- Three special (terminological) meanings (Terminological meanings 1 and 2) corresponding to the content of the concepts.

The scientific concept - I corresponds to the terminological meaning - I. The fact that the same concept can correspond to different meanings (II - 1 and II - 2) reveals a conceptual polysemy associated with the differences at the significative level. Terminological meanings can decay into different variants (terminological meaning variants1.1 and 1.2). Terminological meanings (or their variants) can be decomposed into semes. The correlation between terminological meanings and their variants is set by integrating semes (for example, the integrating seme 1.1.1 +2.2). The differences are indicated by differential semes (for example, the differential seme 2.1).

\section{System of Terminological Meanings}

These peculiarities of the semantic structure of linguistic terms can be correlated with the levels of systemic linkages.

A. Inter-systemic level (relations of the elements of terminological systems in the area of linguistic research, as well as with the systems of other sciences) reveals the phenomenon of polysemy of a linguistic term associated with its correlation with different denotative components or different significative components. The analysis of the denotative level proves the possibility of the existence of a multi-meaning term in linguistics. Its evolution can contribute to the 


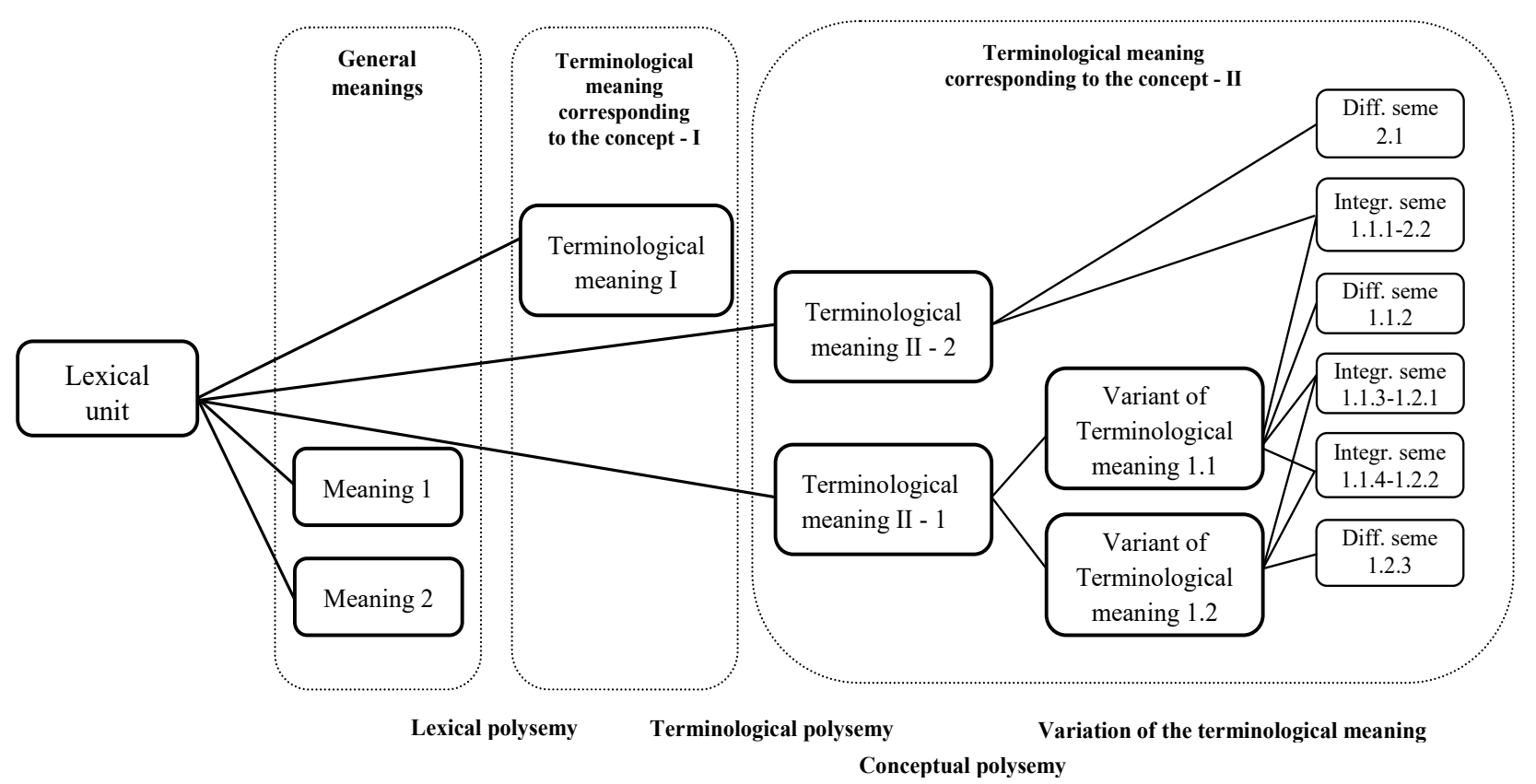

Figure 5. The hierarchical organization of the structure of one lexical unit having terminological meanings.

development of terminological homonymy. The study of terminological meaning in the light of a significative component allowed carrying out a phenomenon of conceptual polysemy of a linguistic term.

B. Intra-systemic level (relations of the elements describing different linguistic theories) reveals $a$ terminological meaning variation associated with the replacement, expansion or restriction of the meaning expressing conceptual indicators. However, this process can develop and promote the formation of conceptual polysemy of the term with a possible transition to other terminological systems as well as a formation of homonyms.

The process of development of a terminological meaning has its own characteristics and requires a careful examination of the specifics features of the semantic evolution of linguistic terms.

\section{Conclusion}

The results of this study demonstrate the need for a careful analysis of polysemy phenomenon in terminological systems. On the one hand, terms being a part of the whole language system have many common features with the elements of the general vocabulary. That is why the method of component analysis can be applied in terminological studies. On the other hand, terms have specific meaning structures. This fact causes the researchers to outline four different types of meaning relations of terms:

1. terminological polysemy caused by the differences at the denotative level ('sémantème' in the theories by A. J. Greimas, B. Poitiers and Ch. Bally);

2. terminological homonymy when there is no linkage between two meanings ('langue' in semantics and phonetics);

3. conceptual polysemy explained by the differences at the significative level ('mot' described from different points of view);

4. terminological meaning variation ('signe' in F. de Saussure's works).

These types of relations are described according to the particularities of linguistic terms developing at inter- and intra-levels. Their polysemy can be explained by the reasons observed at both denotative and significative levels. The latter is of great importance for linguistic terminological systems influenced by differences in interpretation of the same terms as well as by the subjective use of occasional terminological contexts. This research also highlights the importance of comprehensive semantic and terminological approach to the synchronic and diachronic study of terminological systems in French linguistics. Though the given study is limited by the analysis of four French linguistic terms (sémantème, mot, signe, langue), it potentially allows creating the model of a term structure contributing to the analysis of other elements of the French linguistic terminological system in further research.

\section{References}

Bally, Ch. (1932). Linguistique générale et linguistique française [General linguistics and French 
linguistics]. Paris, France: E. Leroux.

Bugorskaja, N. V. (2009). Metodologicheskie problemy opisanija lingvisticheskoj terminologii [Methodological problems of terminological systems description] (Unpublished doctoral dissertation). Moscow State University of Education, Barnaul, Russia.

Bursina, O. A. (2014). Terminologija social'noj raboty: Struktura, semantika $i$ funkcionirovanie [Terminology of social work: Structure, semantics, functioning] (Unpublished doctoral dissertation). Saint Petersburg University, Saint-Petersburg, Russia.

Gadaborsheva, M. U. (2008). Sistemno-dinamicheskij analiz lingvisticheskoj terminologii: $\mathrm{Na}$ materiale russkogo, anglijskogo $i$ ingushetskogo jazykov [Systemic and dynamic analysis of linguistic terminology: Based on the material of the Russian, English and Ingush languages] (Unpublished doctoral dissertation). Southern Federal University, Rostov-on-Don, Russia.

Geeraerts, D. (2010) Theories of lexical semantics. Oxford, UK: Oxford University Press.

Greimas, A-J. (1980). Sémiotique: Dictionnaire raisonné de la théorie du langage [Semiotics: The rationale dictionary of language theory]. Paris, France: Classiques Hachette, Hachette Université.

Grinev-Grinevich, S. V. (2008). Terminovedenie [Terminology]. Moscow, Russia: Academy.

Joseph, J. (2012) Saussure. Oxford, UK: Oxford University Press.

Kharitonova, I. V. (2004). Sistemnoe issledovanie jazyka: Filosofsko-metodologicheskij aspekt [System analysis of the language: Philosophical and methodological approach] (Unpublished doctoral dissertation). Moscow State University of Education, Moscow, Russia.

Khodakova, A. G. (2010). Sistemnaja semantika termina: $\mathrm{Na}$ materiale anglojazychny terminov interneta [Systemic terminological semantics: Based on the English Internet terminology] (Unpublished doctoral dissertation). Tula State Lev Tolstoy Pedagogical University, Tula, Russia.

Kobozeva, I. M. (2009). Lingvisticheskaja semantika [Linguistic semantics]. Moscow, Russia: Knizhnyj dom Librokom.
Kosova, M. V. (2003). Russkaja lingvisticheskaja terminologija: Semanticheskie processy [Russian linguistic terminology: Semantic processes]. Volgograd, Russia: VSU.

Kulikova, I. S., \& Salmina, D. V. (2002). Vvedenie $v$ metalingvistiku: Sistemnyj leksikograficheskij i kommunikativno-pragmaticheskij aspekty [Introduction into the metalinguistics: Lexicographical and communicative pragmatic system aspects]. Moscow, Russia: Vertikal.

Leitchik, V. M. (2012). Terminovedenie: Predmet, metody, struktura [Terminology: Object, methods, structure]. Moscow, Russia: Librokom.

Saussure, F. (1997). Cours de linguistique générale [General linguistics courses]. Paris, France: Hachette.

Saussure, F. (2002). Ecrits de linguistique générale [Writings in general linguistics]. Paris, France: Gallimard.

Saussure, F. (2006). Writings in general linguistics. Oxford, UK: Oxford University Press.

Shurigin, N. A. (2005). Semasiologicheskij i leksikograficheskij aspekty opisanija terminologicheskoj leksiki [Semasilogical and lexicographical aspects of the description of terminological vocabulary]. Nizhnevartovsk, Russia: NUHS.

Slozhenikina, Y. V. (2010). Terminologicheskaja variativnost': Semantika, forma, funkcija [Terminological variation: Semantics, form, function]. Moscow, Russia: LKI.

Sternin, I. A. (1979). Problema analiza struktury znachenija slova [Problem of the analysis of the words' meaning structure]. Voronezh, Russia: VSU.

Strehlow, R. (1997).Frames and the display of definitions: Basic aspects of terminology management (Vol. 1). Amsterdam, Netherlands: Benjamins publishing company.

Tsybova, I. A. (2002). Essai de lexicologie française [Essay on French lexicology]. Szczecin, Poland: Wydawnictwo naukowe Uniwersytetu Szczecinskiego.

Weissenhofer, P. (1995). Conceptology in terminology: Theory, semantics and word formation. Vienna, Austria: TermNet. 